\title{
'Readiness', Talent Management and Adaptive Solutions to enable Teachers in Indigenous Schools to Improve their Teaching
}

Tina Doe, Royce Willis, Lewes Peddell, David Lynch, Tony Yeigh, and Sarah James, Southern Cross University, Australia

\begin{abstract}
This paper provides an insight into an explorative school-improvement program, known as the Indigenous Schools 'readiness' Program (ISRP) which sought to deal with educational challenges in a novel, yet evidenceinformed manner. Specifically, the program sought to engage a school's teaching staff, what is referred to as the Talent in the program, to deal with localised Indigenous school challenges by having them conceptualise and deliver their improvement plans through three inter-related elements: 'readiness', Talent and Adaptive Solutions. The paper suggests that despite the best intentions of parties involved, establishing and maintaining such a program, at least to the point of being able to properly implement and evaluate it, requires that the schooling context, i.e., the community in which it serves, has first created the required community conditions. In effect, engaged its own adaptive solution to inherent challenges.
\end{abstract}

Keywords: Teaching, Education, Indigenous Schools, Talent Management

\section{Introduction}

Educating indigenous students in regional and remote areas of Australia has had a long history of reports and inquiries, each identifying significant challenges and poor schooling performance, with urgent calls for action (Department of the Prime Minister and Cabinet, 2020; Hogarth, 2018; Wilson, 2013). This is symptomatic of the challenges that governments face in providing education services generally in regional, rural and remote locations of Australia (Lamb et al., 2015; Halsey, 2018). In the remote Indigenous schooling contexts, these challenges manifest more intensely and detrimentally in an inter-play of isolation, cultural 
International Journal of Innovation, Creativity and Change. www.ijicc.net

Volume 14, Issue 11, 2020

conflicts, English ---the language of instruction--- not being the local dialect, poverty, entrenched community dysfunction and perhaps understandably, high teacher turnover (Hall, 2012; Brasche \& Harrington, 2012). It is no surprise to learn that the performance of indigenous students in these communities continues to be substantially lower than non-indigenous students, especially when considered nationally (Department of Prime Minister and Cabinet, 2020; Ehrich et al., 2010). Figure 1 is indicative of such results during the period 2008 to 2018. The fundamental challenge in all this is understanding how best to deal with what is proving to be a system of intractable challenges.

Figure 1: Proportion of students meeting the national minimum standard in reading 2008 to 2018 Source: ACARA (2018)

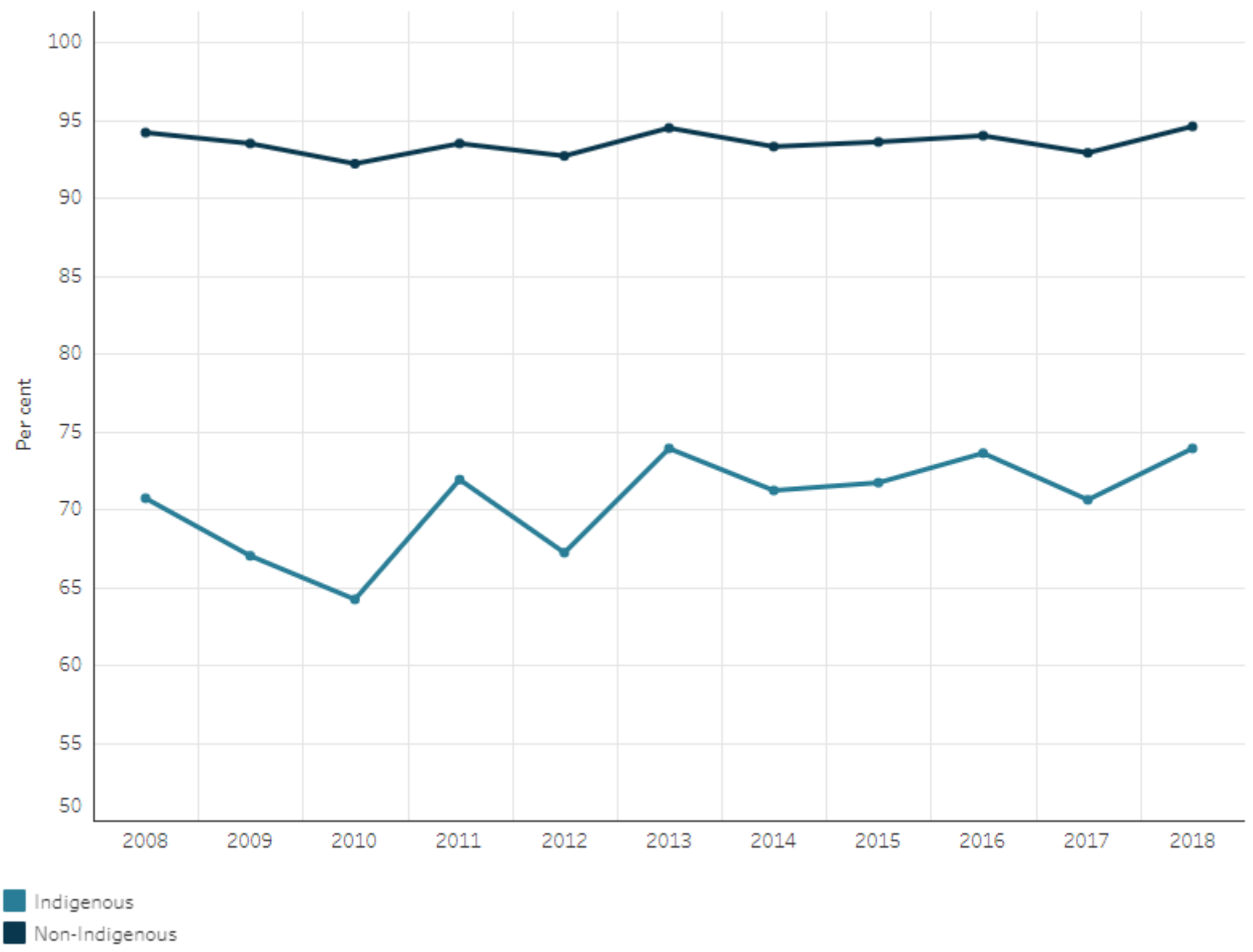

This paper provides an insight into an explorative school-improvement program, known as the Indigenous Schools 'readiness' Program (IRSP). The IRSP is underpinned by a three-part initiative that was operationalised through a tri-phase implementation model that sought to engage a school's teaching staff to tackle localised indigenous school challenges by conceptualising and delivering improvement plans. Thus the following sections of this paper provide a concise outline of the theoretical framework that underpins the ISRP, situates this framework within the three-phase implementation process, reports on how the ISRP was 
operationalised and concludes with a reflection on the enduring challenges that remain in these schools.

\section{Theoretical framework}

The logic of using these three elements emerged from the collective work of Burgess et al. (2019), Hargreaves and Fullan (2012) and Schiemann (2012; 2014), and the ongoing research programs conducted by authors, see Lynch et al. (2019), Lynch et al. (2017), Lynch et al. (2015) and Lynch \& Smith (2016) and Doe (2013; 2014; 2018). Specifically, regarding the research conducted by these authors, what has emerged is a consensus around a three-part framework, initially conceptualised by Schiemann (2012), and its application to create a state of 'readiness' for improvement in educational settings.

At the core of this framework are the key concepts of Alignment, Capabilities, and Engagement (ACE). Conceptually these elements can be understood as (1) Alignment - the synchrony of people with the goals, clientele, and brand of the organisation, wherever they are located within it; (2) Capabilities - the knowledge, skills, information and resources that initially resides, and consequently can be enhanced, in the 'talent' (people) of an organisation, and (3) Engagement - the satisfaction, commitment and willingness the 'talent' to act for the benefit of the organisation in a discretionary way.

\section{Three-phase implementation}

The implementation model

There are three interrelated phases in implementing the ISRP: (1) readying, (2) focusing the 'talent', and (3) generating adaptive solutions. These are conceptually modelled in Diagram 1.

Diagram 1: Indigenous Schools 'Readiness' Program (IRSP): Conceptual elements Intractable Challenges

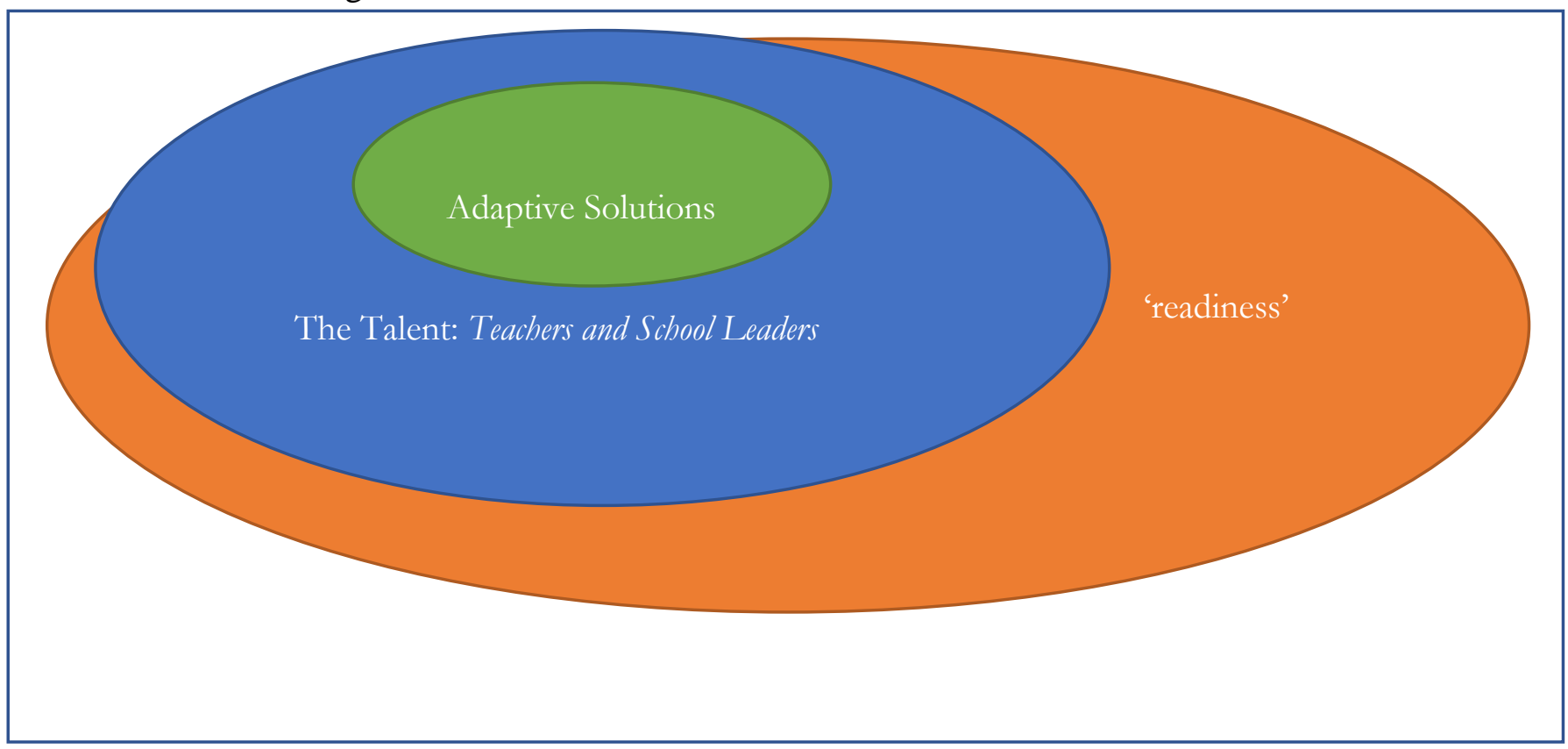


This model can be interpreted as the necessary three phases of implementation such that in Phase 1 'Readiness' is positioned within the domain of what is assumed to be the intractable challenges. Then within the construct of readiness is generated Phase 2, the focus on the 'talent', the people of the organisation who become aligned to the issues of the intractable challenge and through processes of alignment and capability building are prepared to engage and act upon it. This leads to Phase 3 the development of adaptive solutions that are then applied to the intractable challenges. It is important to restate that the ACE framework permeates all phases of this implementation model. We now expand upon these phases to provide further insight into key considerations in their implementation.

\section{Phase 1: Readying the Talent for Teaching Improvement}

Our concept of creating a readiness to engage in teaching improvement is derived from the theory of 'readiness for teaching improvement' as the framework for professional growth and development as established in Lynch et al. (2019), Lynch et al. (2017) and Lynch \& Smith (2016). Specifically, Lynch and Smith (2016) define 'readiness' as the state in which the organisational conditions are such that school staff are prepared to engage in a multifaceted improvement agenda. Leaders within the organisation not only have day-to-day administrative requirements in their position descriptions but are also the people ideally situated to optimise people investments. Great leaders, Izzo suggests (cited in Schiemann, 2014, p. 283), 'know how to optimise their talent by focusing it, developing the right capabilities, and creating engagement'. Thus, if a leader doesn't have people who are aligned with the goals and vision, have effective competencies and are engaged in the task at hand, then we suggest that something is fundamentally wrong. The leadership and school effectiveness literature are awash with this insight (Lynch et al., 2015; Hargreaves \& Fullan 2012).

The 'readiness' approach is geared to view staff not as 'simply employed' but as a set of talented people 'embedded' in the organisation, wanting to be fully enabled and positioned to achieve. This approach has compelling characteristics in so far as it links the recruitment, training, retention, satisfaction, and effectiveness of staff with a school's vision and goals, without the cultural baggage and connotations of 'a teacher in a school' and, provides an alternative view of the school as a well-honed organisation. In this way, the strategic focus and energy are vested in the staff, where each becomes recognised as the organisation's chief resource, i.e., its 'Talent'.

The leader, while part of the talent set, is charged with synchronising and enabling 'The Talent' collectively for overall school improvement effects and in doing so they recognise that staff have to be consulted and prepared accordingly for what is in store. Importantly, each member in the 'readiness' context comes to see clearly what their interlinked role in the improvement equation is and to appreciate, as being engaged in the ISRP, that they now have a set of responsibilities to achieve operational goals and commitments. The 'readiness' process asks 
leaders and their staff to rethink their respective modus operandi through the ACE framework as they prepare their organisation to embark on school improvement strategies and programs. In summation, these categories provide the leaders of the school with an insight into aspects of the current state of staff 'readiness' that require attention to fit and optimise an improvement program such as the ISRP. This, in effect, becomes the talent management strategy. The three categories of ACE together also form an indicator of how the school overall is travelling and accordingly, instruments have been developed by the authors to measure such category of 'readiness' (see Lynch et al., 2019; Lynch et al., 2017; Lynch \& Smith, 2016). The ACE framework can be thought of as a 'canary in the mine', a litmus test of organisational 'readiness' to commence change and innovation initiatives and programs.

\section{Phase 2: Focus on the Talent: School Leaders and their Teachers}

Following on from the element of 'readiness' comes a focus on 'talent', the people of the organisation. Recall that our premise is to consider the school's staff as its 'Talent' who require preparation, enabling and synchronising for positive effects. This preparation, enabling and synchronising strategy, Schiemann, $(2014,2012)$ has termed talent management and is meant as a contrast to traditional approaches synonymous with 'supervision' and 'command and control' regimes. In remote indigenous schools, school leaders, teachers, community members and support staff form 'The Talent.' While school leaders and teachers are an obvious focus, it is crucial to also consider that role of support staff who often form the critical link between the school and the indigenous communities they serve. Furthermore, support staff are often 'local' community members, act as teachers and are the anchors that secure student learning and wellbeing, especially in turbulent, high teacher turnover, environments (Doe, 2006).

We are assisted in our understanding of the important role played by 'The Talent' (school leaders and teachers) in student learning outcomes by John Hattie (2009, 2012, 2016). Hattie (2009), who conducted a synthesis of over 800 meta-analyses relating to student achievement, identified six factors that have been found to impact student achievement. (p. 31). Thus, attempting to control and marshal these factors for positive effects provides an insight into what needs to be focused on if teaching improvement is to be enacted. While acknowledging a range of elements that are typically outside the control of schools, the spotlight shines on the teacher and the school leader (Lynch, et, al, 2015; Hattie, 2009; Hargreaves \&Fullan, 2012), hence the Talent focus.

Consequently, ISRP first recognises the potency of and the necessity for talent management as outlined, and second, prepares the Leader to effectively position the collective 'Talent' to generate solutions to meet the local circumstance. Missing in the logic thus far is a focus, catalyst and mechanism for activating and sustaining the teaching improvement agenda. Hence, we introduce the concept of adaptive solutions. 


\section{Phase 3: Adaptive 'Solutioning'}

Adaptive solutions are operationalised to deal with a complex system of ambiguous problems or opportunities that are often systemically and/or locally generated with no readily understood answers (Heifetz \& Laurie, 1996). In remote schools, these problems are difficult to deal with as they manifest in the circumstances perceived beyond the scope of the school's operations and for which there are often no known or no tangible solutions. Remote indigenous communities with inherent characteristics such as local dialects and little or no English, poverty and community dysfunction, are best addressed by 'adaptive solutions' driven by an innovation and creativity mindset (Lynch et al., 2015; Fullan \& Hargreaves, 2012; Mulford, 1998). An adaptive solution becomes an approach to solving context-specific problems by applying innovation and creative thinking and co-opting others from outside the school to increase capacity to adapt the 'local system of things' for specific localised outcomes. In effect, 'Talent' is positioned in the mind and deeds within and without the school to adapt the 'local system of things' to generate a solution adapted to the specific context (Timperley et al., 2017). Adaptive 'solutioning' comes to mean bringing 'Talent' to bear on intractable challenges through collaboration, creativity, innovation and leadership.

\section{Operationalising the Indigenous Schools 'Readiness' Program (ISRP)}

\section{Participant Schools}

The three schools, all located in very remote Indigenous communities of Australia, were the collective focus of the ISRP. Each school shared similar community circumstances and a clear goal of wanting to support their teachers to enhance practice in a context of significant intractable challenges in their communities which manifest through remote location and specific geo-social circumstances.

School 1 was a primary school with 26 teachers, 399 indigenous students and an average attendance rate for indigenous student $69 \%$. In addition, School 2 was a secondary school with 33 teachers, 298 mostly indigenous students and an average attendance rate for indigenous students of $65 \%$. In completing the group of schools that were the focus of this study, School 3 was a K - 12 school with 42 teachers, 576 students and an average attendance rate for indigenous students of $43 \%$. Two of the three schools are located within a large community with a population of approximately 3250 people in a geographically remote location and the third school is located in a smaller, even more remote community of approximately 2300.

\section{Setting up the Project}

Prior to the start of the ISRP, it was apparent to the authors that the three schools were caught in an unrelenting cycle of unproductive school improvement initiatives in an attempt to meet continuous improvement targets as articulated in various government schools policy documents (see, for example, NTDE, 2019; 2019a; 2019b.). These schools were seeking to meet these targets by delivering a multitude of 'withdrawal from class' workshop style 
Professional Development programs that, as shared with the researchers at the commencement of the project, had little or no impact. The lack of successful outcome from withdrawing teachers out of class for professional learning is noted in the literature on effective teacher professional learning (see Opfer \& Pedder, 2011; Doe, 2011, 2013, 2014).

Drawing on the authors previously published teaching improvement work (see for example: Doe, 2013; Lynch et al., 2019; Lynch et al., 2017; Lynch et al., 2015; Lynch \& Smith, 2016), a meeting of school leaders in each school where issues were shared, and preliminary discussions commenced around potentials for future actions. In short, the school leaders sought a strategy that they could customise within a schooling environment plagued with two key challenges (a) low student motivation to learn and (b) a corresponding lack of community involvement in the school. School leaders deemed overcoming these two challenges as central to improving their schools. Following these revelations, the logic of ISRP, i.e., ACE framework and tri-phase implementation, was introduced and explained, and the ISRP commenced. Implementation

The following provides a narrative of an ongoing project and one which will be reported in full at a later time.

\section{Phase 1: Readying the Talent for Teaching Improvement}

To investigate the level of staff 'readiness', each member of staff completed an online survey developed by the authors, where the three parts of the theoretical model were investigated. We hasten to point out that the survey was inclusive of all staff, including non-teaching staff - who were rightly considered to be key stakeholders and influencers in a people-intensive organisation such as a school. The product of this survey was (a) a detailed indication of the staff's 'readiness' for teaching improvement that is compared to 'like' and 'high performing schools' in terms of Alignment, Capabilities and Engagement, and (b) what the school leader must focus on if their staff are to be ready for the adaptive solution proposed for school improvement. ${ }^{1}$

The staff 'readiness' for improvement data was complemented with a review of data associated with the school, including attendance rates, student performance, community feedback and critical incidents. This process of examining and critiquing the data was undertaken by teachers and the community to construct a series of baseline measures against which success was to be determined and, perhaps more importantly, to glean tangible insights into the current situation in each school that provided glimpses into the intractable challenges that were playing out.

An example of this complementary data was the relatively low average indigenous student attendance rates that through a process of probing was found to significantly fluctuate due to cultural dynamics, e.g., seasonal and ceremonial activity, which by education system standards,

\footnotetext{
${ }^{1}$ Would be great to be able to share some of the outcomes from the data here.
} 
was taking students away from their curriculum-based learning. Therefore, encouraging and sustaining student attendance was considered of paramount concern and a particularly difficult conundrum complicated by a range of factors, not the least being the lack of teacher and school leader service due to high turnover, at rates substantially higher than state and national averages resulting in 'short term stays' (Hall, 2013).

Another example was that of student engagement and motivation to learn, especially as the focus was and continues to be, on a state-based schooling curriculum. The intractable challenge was how to acknowledge and embrace how indigenous students learn so that they are able to walk in both worlds (Bat \& Doe, 2007). This led to a realisation that students in these communities need to develop personal knowledge and skill for the modern world as well as for their indigenous cultural world. Furthermore, it is important to understand that for the Indigenous students in all three of the schools, an ancient tribal value system is the foundation of who they are - it is their dreaming, language, culture, song-line and totem (Doe, 2018). To appreciate and embrace such an understanding was identified as a pivotal step in achieving successful indigenous schooling (Burgess et al., 2019). A crucial to this understanding was for each school to mesh the traditional curriculum with the cultural perspectives of each community, and to do this with predominantly non-indigenous teachers working in concert with the local community and its elders (Bat, Ober, Doe et al., 2011)

The results of this stage, while confirming most of the school leaders' initial thoughts, also provided the new information regarding the work that needed to be done in the school and thus firmed up the project. This process of inquiry produced a series of targets that were collectively agreed upon by the school - its leaders and staff - and their community. In turn, these targets were used to monitor project performance and became a context for project reporting.

\section{Phase 2: Focus on the Talent: School Leaders and their Teachers}

In response, the school's leadership now begins to sustainably build the required states of alignment, capability and engagement in staff and in doing so they focused their endeavours to collegiate work associated with the adaptive solution. Further to this understanding is a realisation that there are key arrangements which the school's leadership needs to engineer within the school to the ACE framework. These arrangements manifest first in the school's leadership, playing a key role in orchestrating and positioning their Talent for the required work. There is a distinct movement towards the attributes of Talent Management as previously outlined, and a refocusing of leaders working, in situ, to that of the requirements of each teacher and away from non-essential administrative matters. This is actioned through the implementation of a formalised coaching mentoring and feedback regime as the vehicle for building ACE in each teacher. A series of additional 'readiness' surveys were conducted to gauge 'Talent' reactions to progress and to ascertain progressive 'readiness' states. From these surveys, corrective actions were made and a cycle of continuous Talent Management emerged. 


\section{Phase 3: Adaptive 'Solutioning'}

School leaders identified an opportunity for an adaptive solution through a Science, Engineering, Technology and Mathematics (STEM) initiative that had been recently launched by the state Department of Education. In effect, school leaders saw in STEM the potential to enrol their community elders, who hold much influence over young people in their schools, to work with them on a curriculum matter that was practical, highly job focused, and thus motivating for students in an indigenous schooling context.

For the schools, the relevant community and its students, a variety of conversations commenced, and from these, an agreement to rethink the respective school's curriculum approach and how students and members of the community would engage with it through STEM was triggered. For teachers, STEM became the central curriculum theme in their school and the focus of each teacher's professional learning. In effect, an approach to solving problems locally by applying innovation and creative thinking and co-opting others from outside the school (the authors and their University) to increase capacity to adapt the 'local system of things' for specific localised outcomes was undertaken.

\section{The role of the researchers}

For the authors involved in this program, our role was to provide ongoing advice and guidance to leaders. We aimed to facilitate the growth of each school leader by acting as a coach, mentor, and a critical friend. In this role, we aided in compiling various research reports ${ }^{2}$ and managed the 'readiness' of the survey process to provide timely and informative information to each school's leadership team. The coalescence of these activities allowed us an opportunity to maintain the necessary momentum and interrogation of the ongoing adaptive solution strategy.

\section{Reflections on the enduring challenges}

We acknowledge the complex and challenging nature of working in remote indigenous schools, and that meeting these challenges is likely beyond the regular capacities of a school to cope. In the very least, one cannot view the improvement of these schools situated in remote indigenous communities through the same lens in terms of what is expected of schools in large metropolitan areas. While the commentary in this paper seeks to exemplify how innovation in school improvement can be undertaken in differing locations, we feel the paper would not be complete without a brief outlining of what we have observed in the ISRP context thus far. Thus we make three observations in that context and in revealing these observations, we draw on program implementation diary notes and transcripts of interviews conducted with teachers, school leaders and community members. 


\section{Observation 1}

The implementation of this program has been most difficult for all concerned, primarily because of the high turnover of both teachers and school leaders. For us as 'outsiders' accessing each site was a full day of travel: an example of the challenges of remoteness when 'outside eyes' are an ingredient. It is apparent that living and working in such communities is a significant challenge to people assigned to such schools. The culture shock of living in such communities, the sheer remoteness of the community, together with ongoing social problems, appears to make an appointment very challenging for most teachers. As an example, during our time in such communities, there were reported suicides of both teachers and students. Continuity of the program in a context such as described here is largely left to a small number who remain for a sustained period and as legacy work, to the authors as project advisers. As you'd appreciate this is far from ideal and there was a sense of constantly having to reinitiate and recalibrate each school's ISRP.

\section{Observation 2}

This observation, revealed in various conversations with teachers and school leaders, was an increasing sense of ownership to the 'adaptive solution' that was planned in each school. Teachers, despite the conditions outlined above, believed in what they were trying to achieve. Teachers commented that their relationship with the school's leadership had improved greatly, especially as the leadership tended to focus their work less on what staff viewed as 'nonessential' tasks (administration) and 'supervising and checking' to coaching and mentoring them to improved practice. Teachers also tended to indicate students were more involved and attentive in classes; however, indigenous student attendance did not appear to improve: a reflection perhaps that issues were deeper than just 'wanting to learn'. Overall, this is a promising insight; however, once again, the continuity of people involved impacted on and tended to derail any long-term improvements.

\section{Observation 3}

As learnt through our interactions and communications with community members, we felt there was a real sense of urgency in community members to improve schooling and in turn, to motivate students to see value in their education. The fact that community members were consulted and, in many cases, became involved in assisting with the STEM curriculum, gave them a sense of pride and optimism. Unfortunately, this optimism tended to ebb and flow as staff changes occurred and as the community became distracted by events outside the school.

\section{Summary and Conclusion}

The ISRP comes to represent a theory on how to conceptualise a school improvement program that has a focus on a school's talent and on moving the leadership of a school from 'supervision and checking' to one that is concerned with building the required states of alignment, capability and engagement of staff to matters at hand. The adaptive solution comes to represent a collaborative catalyst for the school's global community to engage in and work towards solving 
International Journal of Innovation, Creativity and Change. www.ijicc.net

Volume 14, Issue 11, 2020

key localised problems and impediments to school effectiveness. Taken together, the ISRP has the hallmarks of an innovation that positions teachers to achieve optimal learning outcomes for their students. However, as the insights of this paper outline, establishing and maintaining the ISRP, at least to the point of being able to properly implement and evaluate it, requires a schooling context where the community in which it serves has first met its own adaptive solution. It appears to us that this type of work in this type of context is perhaps beyond the regular capacities of the individual schools who are faced with extraordinary, intractable challenges. This is not a comment on schools not wanting to commit and indeed succeed but a comment on how local circumstances conspire to make the task very challenging for teachers, the system of education and the communities they serve. 
International Journal of Innovation, Creativity and Change. www.ijicc.net

Volume 14, Issue 11, 2020

\section{References}

ACARA (Australian Curriculum, Assessment and Reporting Authority) (2018). NAPLAN achievement in reading, writing, language conventions and numeracy: national report for 2018. Sydney: ACARA. Viewed 15 May 2019.

Bat, M., \& Doe, T. (2007) In real time. International Journal of Knowledge, Culture and Change Management, 7. Common Ground Publications.

Bat, M., Ober, R., Doe, T., Kilgariff, C., Oldfield, J., \& Harrison, A. (2011). A teaching and learning practice framework for Batchelor Institute: A proposal for staff. Batchelor Institute.

Birmingham, S. (2016). AEU's own goal with school funding calculations: Media release. Media Centre. http://www.senatorbirmingham.com.au/Media-Centre/Media-.

Brasche, I., \& Harrington, I. (2012). Promoting teacher quality and continuity: Tackling the disadvantages of remote Indigenous schools in the Northern Territory. Australian Journal of Education, 56(2), 110-125. https://doi.org/10.1177/000494411205600202

Buckingham, J. (2013). Education policy trends in Australia. Independence, 38(2), 6-7.

Burgess, C., Tennent, C., Vass, G., Guenter, J., Lowe, K., \& Moodie, M. (2019). A systematic review of pedagogies that support, engage and improve the educational outcomes of Aboriginal students. The Australian Educational Researcher, 46, 297-318. https://doi.org/10.1007/s13384-019-00315-5

Department of the Prime Minister and Cabinet (2020). Closing the gap report 2020: Australian government (pp. ? - ?). https://www.niaa.gov.au/sites/default/files/publications/closing-the-gap-report$\underline{2020 . p d f}$

Doe, T. (2006). Preparing teachers for remote community work: Look back, look left, look forward and reflect. Garma Festival 2006 Key Forum - Indigenous Education and Training. Yothu Yindi Foundation \& Charles Darwin University.

Doe, T. (2011). Teacher professional learning partnerships in practice (Doctoral Dissertation). CQUniversity ${ }^{3}$.

Doe, T. (2013). A new way to think about teacher professional learning. Primrose Hall Publishing Group.

Doe, T. (2014). An examination of an approach to teacher professional learning. International Journal of Innovation Creativity and Change, 1(3). IJICC. http://www.ijicc.net/index.php/past-editions/14-vol1-issue-3-may-2014.html

Doe, T. (2018). Project 'readiness': A partnership in school improvement. ECER. Bolzano. Workshop, September. https://eera-ecer.de/previous-ecers/ecer-2018-bolzano/

Greenfield, W.D. (1987). Instructional leadership: Concepts, issues, and controversies. Allyn and Bacon.

Hall, L. (2012). The 'come and go' syndrome of teachers in remote Indigenous schools: Listening to the perspective of Indigenous teachers about what helps teachers to stay

\footnotetext{
${ }^{3}$ Sarah: Retrieved from...
} 
International Journal of Innovation, Creativity and Change. www.ijicc.net

Volume 14, Issue 11, 2020

and what makes them go. Australian Journal of Indigenous Education, 41(2), 187-195. https://doi.org/10.1017/jie.2012.13

Halsey, J. (2018). Independent review into regional rural and remote education: Final report. https://docs.education.gov.au/system/files/doc/other/01218_independent_review_acce ssible.pdf

Hanushek, E. \& Woessmann, L. (2010). The high cost of low educational performance: The long-run economic impact of improving PISA outcomes. OECD Publishing.

Hanushek, E. A., \& Woessmann, L. (2011). The economics of international differences in educational achievement. In Hanushek, E., Machin, S., \& Woessmann, L. (Eds.), Handbook of the economics of education (pp. 89-200). Elsevier.

Hargreaves, A. \& Fullan, M. (2012). Professional capital: Transforming teaching in every school. Teachers College Press.

Harris, A. (2013). Distributed leadership matters: Perspectives, practicalities, and potential. Corwin Press.

Hattie, J. (2009).Visible learning: A synthesis of over 800 meta-analyses relating to achievement. Routledge.

Hattie, J., (2016). Shifting Away from Distrations to Improve Australia's schools: Time for a reboot. ACEL Monograph Series: Strawberry Hills: Australia. Retrieved from http://www.acel.org.au/acel/ACEL_docs/Publications/Monograph/Monograph_54_20 16_WEB.pdf

Hattie, J. (2012). Visible earning for teachers: Maximising impact on learning. Routledge.

Heck, R.H., Larsen, T.J., \& Marcoulides, G.A. (1990). Instructional leadership and school achievement: Validation of a causal model. Educational Administration Quarterly, 26, 94-125. https://doi.org/10.1177/0013161X90026002002

Hogarth, M. (2018). Talkin' bout a revolution: the call for transformation and reform in Indigenous education. The Australian Educational Researcher 45, 663-674. https://doi.org/10.1007/s13384-018-0277-8

Ehrich, J., Wolgemuth, J.R., Helmer, J., Oteng, G., Lea, T., Bartlett, C., Smith, H., \& Emmett, S. (2010). Attendance, performance and the acquisition of early literacy skills: A comparison of Indigenous and non-Indigenous school children. Australian Journal of Learning Difficulties, 15(2), 131-149. https://doi.org/10.1080/19404150903524580

Hall, L. (2013). The 'Come and Go' syndrome of Teachers in Remote Indigenous Schools: Listening to Perspectives of Indigenous Teachers about What Helps Teachers to Stay and What makes them Go. The Australian Journal of Indigenous Education. Vol. 41, No. 2, pp 187-195

Kuhn, T.S. (1970). The Structure of Scientific Revolutions, 2nd ed. University of Chicago Press.

Lachat, M.A. \& Smith, S. (2005). Practices that support data use in urban high schools. Journal of Education for Students Placed at Risk (JEPSAR). 10(3), 333-349. https://doi.org/10.1207/s15327671espr1003_7 
International Journal of Innovation, Creativity and Change. www.ijicc.net Volume 14, Issue 11, 2020

Lamb, S., Jackson, J., Walstab, A. \& Huo, S. (2015). Educational opportunity in Australia 2015: Fact sheet 6 - young people in rural and remote communities frequently missing out. Melbourne: Mitchell Institute, Mitchell Institute. https://www.vu.edu.au/mitchellinstitute/educational-opportunity/young-people-in-rural-and-remote-communitiesfrequently-missing-out

Leithwood, K. A. (1992). The move toward transformational leadership. Educational Leadership, 49(5), 8-12.

ASCD. http://www.ascd.org/publications/educational_leadership.aspx

Leithwood, K., Harris, A., \& Hopkins, D. (2008). Seven strong claims about successful school Leadership. School Leadership and Management, 28(1), 27-42. https://doi.org/10.1080/13632430701800060

Leithwood, K., Mascall, B., \& Strauss, T. (2009). Distributed leadership according to the evidence. Routledge.

Lunenburg, F., (2010). The Principal as Instructional Leader. National Forum of Educational and Supervision Journal, 27,(4). National Forum. http://www.nationalforum.com/Electronic\%20Journal\%20Volumes/Lunenburg, \%20F red\%20C.\%20The\%20Principal\%20as\%20Instructional\%20Leader\%20NFEASJ\%20 V27\%20N4\%202010.pdf

Lynch, D. \& Smith. R (2017). 'readiness' for School Reform. International Journal of Innovation, Creativity and Change. 2(3).

Lynch, D., Madden, J. \& Doe, T. (2015). Creating the Outstanding School. Oxford Global Press.

Lynch, D., Smith, R., Provost, S., Yeigh, T., \& Turner, D. (2017). The Correlation between "Teacher 'readiness" and student learning improvement. International Journal of Innovation, Creativity and Change, 3(1), 1-12. IJICC. www.ijicc.net

Lynch, D. \& Smith, R. (2016). 'readiness' for school reform. International Journal of Innovation, Creativity and Change, 2(3). IJICC. http://www.ijicc.net/images/Volume2issue22015/'readiness'_Lynch_and_Smith.pdf

Lynch, D., Smith, R., Yeigh, T., \& Provost, D. (2019). A study into 'organisational 'readiness' and its impacts on school improvement. International Journal of Educational Management, 33(2), 393-408.

https://doi.org/10.1108/IJEM-07-2017-0181.

Marzano, R.J. Waters, T. \& McNulty, B.A. (2005). School leadership that works: From research to results. ASCD.

Mulford, B. (1998). Organisational learning and educational change. In A. Hargreaves, A. Lieberman, M.Fullan, \& D. Hopkins. (eds.). International handbook of educational change. Kluwer.

Nolan, J.F., \& Hoover, L.A. (2011). Teacher supervision and evaluation: Theory into practice (3rd ed.). Wiley. 
International Journal of Innovation, Creativity and Change. www.ijicc.net Volume 14, Issue 11, 2020

Northern Territory Department of Education (2020). STEM in the Territory Strategy (2018 to 2022). Education NT. https://education.nt.gov.au/support-for-teachers/stem-in-theterritory-strategy-2018-2022

Northern Territory Department of Education. (2019). A Share in the future: Indigenous education strategy 2015 to 2024. Education NT. https://education.nt.gov.au/statisticsresearch-and-strategies/indigenous-education-strategy

Northern Territory Department of Education. (2019a). Department of Education strategic plan, 2018 to 2022. Education NT. https://education.nt.gov.au/statistics-research-andstrategies/strategic-plan

Northern Territory Department of Education. (2019b). Department of Education STEM in the Territory strategy 2018 to 2022. Education NT. https://education.nt.gov.au/_ data/assets/pdf_file/0011/591950/STEM-Territory-1822-web.pdf

Opfer, V. \& Pedder, D. (2011). Conceptualizing teacher professional learning. Review of Educational Research, 81(3), 376-407. https://doi.org/10.3102/0034654311413609

Schiemann, W. A., Seibert, J. H., \& Morgan, B. S. (2013). Hidden drivers of success: leveraging employee insights for strategic advantage. Society for Human Resource Management.

Schiemann, W.A. (2012). The ACE advantage: how smart companies unleash talent for optimal performance. Society for Human Resource Management.

Schiemann, W.A. (2014). From talent management to talent optimization. Journal of World Business. 49(2), 281-283. https://doi.org/10.1016/j.jwb.2013.11.012

Shen, J. \& Cooley, V.E. (2008). Critical issues in using data for decision-making. International Journal of Leadership in Education, 11(3), 319-329. http://dx.doi.org/10.1080/13603120701721839

Timperley, H., Ell, F., \& Le Fevre, D. (2017). Developing adaptive expertise through professional learning communities. In Harris, A., Jones, M. \& Huffman, J. Teachers Leading Educational Reform (175- 189). Routledge.

Wilson, B. (2013). A Share in the Future: Review of Indigenous Education in the Northern Territory. NT Department of Education. NT Government. https://www.nt.gov.au/_data/assets/pdf_file/0020/229016/A-Share-in-the-FutureThe-Review-of-Indigenous-Education-in-the-Northern-Territory.pdf

Tschannen-Moran, B., \& Tschannen-Moran, M. (2010). Evocative coaching: Transforming schools one conversation at a time. Jossey-Bass.

Woessmann, L. (2016). The importance of school systems: Evidence from international differences in student achievement. Working paper 5951. ECONSTOR. econstor.eu/bitstream/10419/144986/1/cesifo1_wp5951.pdf 